\title{
AKT1 Gene Rearrangement
}

National Cancer Institute

\section{Source}

National Cancer Institute. AKT1 Gene Rearrangement. NCI Thesaurus. Code C150441.

A molecular abnormality indicating rearrangement of the AKT1 gene. 